DOI: $10.1515 /$ auseur-2015-0002

\title{
Exerting the Principle of Collective Guilt against the Transcarpathian Hungarians and Germans (Carrying into Effect the Decisions of the Military Council of the $4^{\text {th }}$ Ukrainian Front in the Light of the NKVD ${ }^{1}$ Reports)
}

\author{
György DUPKA \\ Memorial Park in Svalyava, Ukraine
}

\begin{abstract}
In his paper, György Dupka deals with the tragic fate of the Transcarpathian Hungarians and Germans deported for 'a three-day labour' in the period of 1944-1946. During the past twenty years, he succeeded in collecting and, in some measure, publicizing sufficient archival materials to open up the facts of the anomies committed by the Soviet military authorities in the fall of 1944 and at the beginning of 1945. All these facts are supported by cogent data and concrete names of the perpetrators. In his paper, the author shows primarily how in the light of the reports conceived by the NKVD and other Soviet central military administrations Order 0036 of the Military Council of the $4^{\text {th }}$ Ukrainian Front was carried into effect.
\end{abstract}

Keywords: Transcarpathia, 1944, the $4^{\text {th }}$ Ukrainian Front, NKVD, collective guilt, 'malenkiy robot,' Hungarians, Germans, Szolyva, labour camps

In the past twenty years, I succeeded in collecting and partially publicizing sufficient archival materials to open up the facts of the anomies committed by the Soviet military authorities against the civilian population of Transcarpathia in the fall of 1944 and at the beginning of 1945. All these facts are supported by cogent data and concrete names of the perpetrators. In this lecture, my purpose is to show, primarily, how in the light of the reports conceived by the NKVD and other Soviet central military administrations Order 0036 of the Military Council of the $4^{\text {th }}$ Ukrainian Front was carried into effect.

1 The People's Commissariat for Internal Affairs (Народный комиссариат внутренних дел, Narodnyy Komissariat Vnutrennikh Del), abbreviated NKVD was a law enforcement agency of the Soviet Union that directly executed the rule of power of the Communist Party of the Soviet Union. It was closely associated with the Soviet secret police, which at times was part of the agency, and it is known for its political repression during the era of Joseph Stalin. 
Because of the abundance of the not so far known materials and information connected with a whole circle of questions signalled already above, I am not going to condescend upon particulars, i.e. upon the historical analysis of all the questions of the Soviet occupation, annexation, and Sovietization. It is not my aim to speak about the retaliatory measures of the Communist dictatorship in Transcarpathia which lasted from the annexation of a territory almost as big as four counties until the dissolution of the Soviet Union in 1991, i.e. from 1945 up to 1991 (Dupka 1914). Due to time and space limits, I cannot go into details concerning the occupancy of Csonka-Bereg (Берег in Ukrainean), East Slovakia (Ung and Latorca/Latorica counties), Máramarossziget (Sighetu Marmației) County and their environments from where the Soviets 'nicked' unlawfully all the men of military age of Hungarian and German extraction (about 10,000 people) (Dupka 1912).

\section{Military and Political Preparations for the Occupation of Transcarpathia by the Soviets, Carrying Them into Effect, Fly-Bill Actions and Establishing Command Posts}

Under the guidance of Stalin, Iosif Vissarionovich, the Marshall Voroshilov, Kliment Yefremovich, the Deputy-Chairman of the State Defence Committee $(\mathrm{SDC})^{2}$ together with Beria, Lavrentiy Pavlovich, who in February 1941 was appointed Deputy-Chairman of the Council of People's Commissars and in June, following the German invasion, became a member of the State Defence Committee (GKO), on the $30^{\text {th }}$ of June, 1944 - in order to seize and occupy Transcarpathia - made a decision that gave rise to the $4^{\text {th }}$ Ukrainian Front at the juncture of the $1^{\text {st }}$ and $2^{\text {nd }}$ Ukrainian Front. In making this decision, they took into account the military and political importance of the occupation of Transcarpathia and the peculiarities of military operations in mountainous areas (Dovkhanitsh 1997: 69).

On the $5^{\text {th }}$ of August, the general headquarters constituted the four-star (colonel-general) Ivan Yukhimovotsh Petrov the commander of the Front, and Lieutenant-General F. K. Korzhenevitsh the commander-in-chief of the staff. Colonel-General Lev Zakharovitsh Mekhlis, who was notorious for his brutality - one of the principals of the SMERSH ${ }^{3}$ and of the NKVD -, started preparing and carrying into effect with elaboration the Carpathian offensive.

2 SDC, Russian: Государственный комитет обороны, ГКО, Gosudarstvennyj komitet oborony, GKO, which was an extraordinary organ of state power in the USSR during the German-Soviet War, and held complete state power in the country instead of the Council of People's Commissars.

3 SMERSH (Russian: CMEPШ, acronym of Russian: Специальные Методы Разоблачения Шпионов; Special Methods of Spy Detection), but also anecdotally referred to as SMERt' SHpionam ('Death to spies'), was an umbrella name for three independent counter-intelligence agencies in the Red 
The operation was successful due to a single military political event, viz. to the Romanian King Michael's coup (coup d'état). As a result, the Axis front in northeastern Romania collapsed in the face of a Soviet offensive, and Transcarpathia 'fell into the lap of the Red Army'. On the $27^{\text {th }}$ of October, 1944, the Soviet troops marched into Ungvár (Ужгород / Uzhhorod in Ukrainean). On this day, a festive order signed by Stalin was proclaimed, which mentioned inter alia 'the seizure of an important bridge-head (tête-de-pont) from a military point of view' (Slyakhom Zhovtnya, 6. 1965: 4). On the same day at 9 p.m. in Moscow, 224 guns fired twenty salutes in honour of the 'glorious troops' of the $4^{\text {th }}$ Ukrainian Front on this occasion (Kutsenko 1970: 16). But the Soviets did not manage to keep Csap (Chop) that was taken by them on the $29^{\text {th }}$ of October. The town changed owners several times, and the Hungarian and German troops withdrew only on the $26^{\text {th }}$ of November to avoid full encirclement. In Ungvár, 2,500 Hungarian and German soldiers were taken POWs. 3,730 Soviet soldiers fell at taking Transcarpathia, out of them 2,730 are known, 417 are unknown (Kerecsanyin 1997: 641).

Beginning with the $28^{\text {th }}$ of October, 1944, the military administration of the $4^{\text {th }}$ Ukrainian Front established command posts with town-majors in the occupied towns and larger settlements: Kőrösmező (in Ukrainean: Ясіня [Jaszinya]), Rahó (Рахів [Rahiv/ Rakhiv]), Alsó-Verecke (Нижні Ворота [Nizsnyi Vorota]), Uzsok (Ужок), Hajasd (Волосянка [Voloszjanka]), Felső-Verecke (Верхні Ворота), Volóc (Воловець [Volovec]), Alsóhidegpatak (Нижній Студений [Nizsnyij Sztudenij]), Gernyésmező (Поляна [Gyilova]), Kaszómező (Косівська Поляна/Koszivszka Poljana], and Nagybocskó (Великий Бичків [Velikij Bicskiv/Velykyy Bychkiv]) in order to consolidate military civil service. Lieutenant-colonel and head of the staff Korzhenevitsh had written instructions for the appointed officers as to how to organize their activity and intercourse with the local population, the detection of the hostile elements, and also their 'guarded' co-operation with the Czechoslovak military administration (TSU 2007: 238. doc., 421-422).

\section{Decree on Exerting the Principle of Collective Guilt}

The archival materials discovered so far unambiguously demonstrate that the designs of the Sovietization of Transcarpathia occupied by the Red Army, the deportation of the Hungarians and Germans were realized under the direction of the NKVD and the active guidance of the $4^{\text {th }}$ Ukrainian Front according to a Muscovite scenario approved by Stalin.

Light was shed on the separate roles of the participants as well. One of the civilian key figures was Ivan Turyanitsa, a communist leader of Transcarpathian

Army, formed in late 1942 or even earlier, but officially founded on 14 April 1943. The name SMERSH was coined by Joseph Stalin. 
issue, who was given by Beria the task to be in command of the annexation of Transcarpathia registered as part of Czechoslovakia on partyline with the help of Bolshevik dummies taking as point of departure Benes's promise to resign Transcarpathia to Stalin.

In order to realize Benes's promise, it was necessary to produce a number of political put-up shows. There were, inter alia, the strengthening of the leading role of the Transcarpathian Communist Party, the establishing of the people's commissariats supporting the annexation of Transcarpathia, conducing to ethnic purifications, the organization of the first congress of the people's commissariats, the proclamation of Transcarpathian Ukraine, the electing of the People's Council, the acceptance of the Manifesto justifying the authenticity of Transcarpathia's 'reunion' with Ukraine, organizing campaigns for signing different petitions, the final showdown with the enemies of the people and the Soviet Union, the curbing and ousting of the Transcarpathian activity of the Czechoslovakian governmental offices, conducing to the Soviet-Czechoslovak negotiations on the fate of Transcarpathia, the realization of the Sovietization programme, etc.

On the $28^{\text {th }}$ of October, 1944, in order to launch the operative things to do, Ivan Turyanitsa, the leader of the Transcarpathian communists devoted to Moscow and as the political officer of the $1^{\text {st }}$ Czechoslovakian Army-Corps and a trained agent of the Soviet secret service had a pow-wow with Army General Petrov, the chief commanding officer of the $4^{\text {th }}$ Ukrainian Front, Nikita Khrushchev Ukrainian party leader (TSU 2007: 413. doc. 695-698) and Colonel-General Mekhlis, the member of the Military Council of the $4^{\text {th }}$ Ukrainian Front. Accompanied by the two latter key figures, he arrived at Munkács (Мукачеве [Mukacseve]) on the same day to make a decision on the fate of Transcarpathia (TSU 2007: 364. doc. 593. 599).

At the party meeting that took place there according to expectations, different decisions were accepted; inter alia, there were proposals for 'a total cleansing in Transcarpathia considered a logistical territory'. The document prescribing the provisional isolation of individuals not to be trusted by the Transcarpathian people (Dupka, Korszun 1997: 11) was signed by Turyanitsa on the $11^{\text {th }}$ of November, 1944. According to the proposals of the decree registered by Major General Fadyeyev, Com. of the NKVD squads in charge of the control of the hinterland of the $4^{\text {th }}$ Ukrainian Front, and Colonel Levin, deputy-commander of the staff, prepared a concept for execution and then its military scenario.

Later, with Stalin and Beria's knowledge, they played a significant role in preparing and executing deportations. Fadyeyev personally proposed to the Military Council of the $4^{\text {th }}$ Ukrainian Front the idea (KU 2009: 353-355) of interning the male population of the settlements inhabited by Hungarians and Germans as the representatives of the enemy because they might prevent the introduction of the Soviet system into Transcarpathia. Fadyeyev and Levitin suggested that from November the $14^{\text {th }}$ to the $17^{\text {th }}$ they should execute the military 
registering of the Hungarian and German men of the age between 15 and 50. (It is not a mistake. At the beginning, boys of levente-age, i.e. who were born in 1927-1929, were also registered - Gy. D.)

The second official registration was already planned for the $18^{\text {th }}$ of November, 1944, with the apprehension (and deportation to the nearest POW camps) of the former Hungarian and German soldiers, officers, functionaries, gendarmes, policemen, and males of military age between 18 and 50 .

On their sitting of November the $12^{\text {th }}, 1944$, the Military Council of the $4^{\text {th }}$ Ukrainian Front consented to their top secret 0036 Decree and approved of its operative execution. It was signed by Army General Petrov and the members of the Military Council of the Front: Colonel-General Mekhlis, Major General Novikov and Battery Lieutenant-General Kariofilli. The document consisting of nine points prescribed the Transcarpathian exertion of the 'principle of collective guilt and punishment' and was approved of by the summit military leadership: 'At a great number of settlements, there are lots of individuals of military age of Hungarian and German nationality who, similarly to all enemy soldiers, must be apprehended and sent to POW camps!' (KU 2009: 219. doc. 353-355).

The decree designated the time of the execution and the age of those to be drafted more exactly, and ordered the leaders of the operation to pay special attention to the following: from the $14^{\text {th }}$ up to the $16^{\text {th }}$ of November, 1944, the military mayors of towns and settlements independently of their nationality should also keep a record of those soldiers and officers who served in the German or Hungarian armies, and - what was still more important - they should register all those German and Hungarian men of military age between 18 and 50 (i.e. civilians who served in none of the armies) who lived on Transcarpathian soil, and also all the officers and employees of the Hungarian police and gendarmerie.

The military commanders were suggested that during the registering they informed everybody that on the $18^{\text {th }}$ of November they are supposed to show up again for the second time, so that all quota, and among them those who were of military age and eligible, would be escorted in columns to concentration camps for POWs.

The Decree mentioned separately the officers and employees of the Hungarian gendarmerie and police who, after registering, had to be given in charge of 'the units of SMERSH and the reconnaissance organs of the border-wardens guarding the logistic areas'. Here, it must be noted that we learnt from the survivors that they had been at once sentenced to death by court-martials, and executed.

The $4^{\text {th }}$ point of the Decree said that up to November 17, 1944 POW camps had to be established in Perecseny (Перечин [Perecsin/Perechyn]) and the surroundings

4 Levente Associations (Hungarian: Levente Egyesületek), or simply 'levente,' were paramilitary youth organizations in Hungary in the inter-war period and during the Second World War. It was established in 1921 with the declared purpose of physical and health training. 
of Huszt (Хуст). Point 5 admonished Major-General Fadyeyev that the NKVD squads controlled by him should exercise a more efficacious work in detecting and arresting the above mentioned individuals. Point 6 admonished Major-General Katznelson to permit the military commanders directing regionally the operation to use Willis motorcars parking at the recruiting places. Point 7 permitted to use the garrison of the settlement commanders for strengthening the escort of the arrested. Pont 8 told the chief of the logistic area to organize a sufficient number of dining stations from the $18^{\text {th }}$ of November, 1944 on the path Ungvár (Ужгород [Uzshorod])Sambor and Szolyva (Свалява [Szvaljava])-Sambor. Point 9 admonished MajorGeneral Fadyeyev again that in order to execute the Decree he should summon the military commanders and their assistants for a conference to be held at three o'clock p.m. on the $12^{\text {th }}$ of November, 1944. On this conference, Fadyeyev let the military commanders and their assistants know the essence of the forthcoming operation and the order of the military commander agreed with the Military Council of the Front. This order had to be announced in all the towns and villages of Transcarpathia on the $13^{\text {th }}$ of November. 'Order 2 of the town's captaincy' was attached to Decree 0036 also with the date November 13.

As we can see, the operation was prepared quickly and circumspectly. The order had been translated into Hungarian, too, and was printed in several hundred copies in the Miravcsik printing house in Ungvár (Ужгород [Uzshorod]). The text of the Hungarian bill was the following:

1) From November the $14^{\text {th }}$ of the present year, within three days all the soldiers and officers who belonged to the bounds of the Hungarian and German armies and remained on the soil of the liberated Transcarpathia are obliged to present themselves at the nearest town's captaincy.

German and Hungarian males of military age from 18 up to 50 are also obliged to present themselves.

2) All those who hired themselves out in the service of the police or gendarmerie during the Hungarian occupation in Transcarpathia are also to be registered within these days of appearance.

3) One can appear at the town's captaincy only from 9 a.m. till 7 p.m. The last day of appearance is the $16^{\text {th }}$ of November, 1944.

4) They who do not meet this engagement will be arrested and sentenced by a court-martial. Town's major (Egyetlen bünük... 1993a: 8).

After November 13, 1944, 'the $2^{\text {nd }}$ order of the town's major' was hung out also in settlements inhabited by Hungarians and Germans. The leaders of the municipalities co-operating with the town's majors thought up this notorious 'three-day labour' or the tale mobilizing the population for bridge and road repairs. This was proclaimed from the house-top by the common criers with 
the addendum that the concerned 'should take for themselves enough food for three days'.

In such a short time (in a day actually), it was difficult to execute all this. Most likely the plan of the operation was elaborated well in advance. However, it turned out later that it was organized with hurry-scurry, it was over-sized and fraudulent, and the consequences of bad provisioning turned out to be disastrous and fatal for many Transcarpathians in the very first days already. The overwhelming majority of the individuals 'to be arrested,' who presented their ID documents on the $16^{\text {th }}$ of November already, on the $18^{\text {th }}$ of November went to the place of appearance to take them back only. But they were not allowed to go home for their personal belongings and food and to take leave from their family members. After the data were checked, they could go out into the yard or to the street with armed escort only. As a matter of fact, they found themselves all of a sudden in camp circumstances. In the yard that became an enclosure and in the streets, the fraudulent misrepresentation, i.e. the fooling of the people collected this way, continued. Viz. the military authorities beguiled them with the promise that they would be sent for 'a little extemporaneous three-day labour' (malenykiy robot) and their provision would be organized on the way. A couple of Hungarian agitators weighing with the folks, among them the guerrilla (partisan) leader Gyula Uszta and Major Béla Illés (the writer), encouraged the people. In some of the settlements, the people going for this 'three-day labour' were sent off ceremonially, with drums and blessings of priests and authorities. It was really difficult to believe that all this was nothing else than a gorgeous farce which was a road to hell and death for the majority of the crowd.

\section{Preparing the Units Taking Part in the Operation of Carrying out the Deportations}

We managed to find evidence in form of detailed instructions concerning the collection of Hungarians and Germans (TSU 2007: 250. doc. 433-435). Major Portnyagin, the head of one of the departments of the NKVD squads belonging to the $4^{\text {th }}$ Ukrainian Front issued 'a top secret' order (0047. 15. 11. 1944) for the NKVD units executing Decree 0036. This order gave the murderous genocidal machinery of the NKVD and the SMERSH a boost. It set the ball rolling and the seeding, isolating, collecting, arresting, internment, and deportation of the population were executed most rigorously.

Quite recently, more top secret NKVD reports connected with the execution of Decree 0036 turned up in the Russian State Military History Archives in Moscow. The operational tasks were directed personally by Colonel-General L. Mekhlis, who received detailed reports ever day from Major General Fadyeyev, who 
was the commander-in-chief of the NKVD troops co-ordinating the execution and guarding the logistical areas. More NKVD reports inform the boss about the events and the emerged situation of the period between November 18 and December 17, 1944. Detailed numerical data show the results of the registrations scheduled by the Decree, the arrest of the target persons, and their division into groups according to their military ranks and nationality. Sixteen town captaincies participated in this operation. And namely that of Ungvár (Ужгород [Uzshorod]), Munkács (Мукачеве [Mukacseve]), Beregszász (Берегове [Berehove]), Nagybereg (Великі Береги [Veliki Berehi/Velyki Berehy], Huszt (Хуст), Tiszaújlak (Вилок [Vilok]), Nagyszőlős (Виноградів [Vinohragyiv]), Bátyú (Батьово [Batyovo]), Kövesliget (Драгово [Drahovo]), Perecseny (Перечин [Perecsin/Perechyn]), Poroskő (Пороwkobo [Poroskovo]), Kaszómező (Косівська Поляна [Koszivszka Poljana]), Szolyva (Свалява/Szvaljava), Szerednye (Середнє [Szerednye]), Nagyberezna (Великий Березний [Velikij Bereznij]), and Kisberezna (Малий Березний [Málij Bereznij]). A list was prepared of the isolated Slav nationalities (Ukrainian, Roussin, Slovak, and Czech), while cumulative data were reported about the arrested who were directed with armed guidance to POW concentration camps. There was also a list of those individuals who did not appear for the second registration in the appointed time (on the $18^{\text {th }}$ of November). Finally, it made a report about the persons who were in hiding but were arrested and escorted into a concentration camp. The numerical data of the tables that may be read in these reports are shocking proofs of how circumspectly and comprehensively was ethnic cleansing (purification) organized in settlements inhabited by Hungarians and Germans. The further reports also witness the blows of the speeding up and murderous machinery of the NKVD on the Hungarians, Germans, and Krauts.

More people in the columns directed from Szolyva (Свалява [Szvaljava]) into the concentration camp in Turka (Lemberg/Lvov/Lviv territory) fled. In this respect, a minute-book (TSU 2007: 262. doc., 447-448) was found signed by convoy commander Lieutenant Kulik, assistant commander Sub-Lieutenant Belitsky, Sergeant Bozin, Buck Sergeant Zub, and Red Army privates Pizhikov and Zhaludkov. The signers signalled towards their superior, the commander of Battalion 159 securing the convoy that at night on the road leading from Poljana to Verecke (Szerednyovereckij) 51 persons, most of them Jews, fled from the column consisting of 2,000 people escorted by 42 armed guards. A unit, with the co-operation of the command of a border warden squad located in the area of the Polish-Czech border, started the search of the disappeared, and on the $22^{\text {nd }}$ of November they found sixty-five persons without any papers in the surrounding woods. All of them were sent to the concentration camp in Szolyva (Свалява [Szvaljava]). After the combing out of the Roussine villages, the discovered persons of German and Hungarian nationalities were also registered and sent to the nearest concentration camp. 
The aggregate dispatch (TSU 2007: 262. doc. 447-448) of December 17, 1944 also contained surprisingly interesting data. Compared to the documents mentioned above, there are still more detailed accounts of the cleansing operations of the NKVD units on the loot in Transcarpathia. This report was sent by Major General Fadyeyev and Colonel Bosiy to Army General Petrov. The registry number of the three-page typed document is 5032P. Major General Fadyeyev wrote, inter alia, in his report the following: 'Executing Decree 0036 of the military Council of the Front accepted on the $13^{\text {th }}$ of October, 1944, the NKVD squads screening the logistic area on the territory of Transcarpathian Ukraine isolated the officers and privates of the enemy, the German and Hungarian men of military age, the gendarmes of the Hungarian gendarmerie, and the officers of the Hungarian police, and directed them to POW concentration camps.'

Table 1. A survey of people directed to POW camps according to their nationality: November 18 - December 16, 1944

\begin{tabular}{llccccc}
\hline No. & Nationality & Officers & Men & $\begin{array}{c}\text { Of military } \\
\text { age }\end{array}$ & $\begin{array}{c}\text { Policemen, } \\
\text { Gendarmes }\end{array}$ & $\begin{array}{c}\text { In the } \\
\text { aggregate }\end{array}$ \\
\hline 1. & Hungarian & 132 & 7669 & 7025 & 164 & $\mathbf{1 4 9 9 0}$ \\
\hline 2. & Czech & 3 & - & - & - & $\mathbf{3}$ \\
\hline 3. & $\begin{array}{l}\text { Roussine } \\
\text { (Ruthene) }\end{array}$ & 16 & - & - & 5 & $\mathbf{2 1}$ \\
\hline 4. & Slovak & 3 & - & - & 1 & $\mathbf{4}$ \\
\hline 5. & German & - & 60 & 68 & 1 & $\mathbf{1 2 9}$ \\
\hline 6. & Ukrainian & - & - & - & 4 & $\mathbf{4}$ \\
\hline 7. & Romanian & - & - & - & 1 & $\mathbf{1 5} \mathbf{1 5 2}$ \\
\hline In the aggregate: & $\mathbf{1 5 4}$ & $\mathbf{7 7 2 9}$ & $\mathbf{7 0 9 3}$ & $\mathbf{1 7 6}$ & $\mathbf{1 5}$ \\
\hline
\end{tabular}

The table shows that this time the officers, policemen, and gendarmes of Czech, Roussine, Slovak, Ukrainian, and Romanian nationalities were not acquitted either; as 'guilty elements,' they were also sent to transit camps together with the ones of Hungarian and German nationality. 'Encamping' was avoided by soldiers and men of military age confessing the Orthodox and Greek Catholic religion only. They were allowed to go home or could ask their conscription into the Red Army. Many of them did so.

Table 2. An aggregate survey of people directed to transit POW camps: November 18 - December 16, 1944

\begin{tabular}{llcccc}
\hline No. & Nationality & $\begin{array}{c}\text { Officers and } \\
\text { privates }\end{array}$ & $\begin{array}{c}\text { Of military } \\
\text { age }\end{array}$ & $\begin{array}{c}\text { Policemen and } \\
\text { gendarmes }\end{array}$ & $\begin{array}{c}\text { In the } \\
\text { aggregate }\end{array}$ \\
\hline 1. & $\begin{array}{l}\text { Hungarian } \\
\text { and German }\end{array}$ & 14202 & 8564 & 185 & $\mathbf{2 2 ~ 9 5 1}$ \\
\hline
\end{tabular}


This dispatch was closed with the report saying that 'from November 18 to December 16, 1944, 22951 persons were arrested and sent to transit POW camps by the NKVD squads' on the territory of Transcarpathia. It was also noted that 'the operation for cleansing the logistical area continues'. This judicial document sheds light on the fact that the confiding Hungarian and German/Kraut male population was rived from their families with a disloyally thought-up tale mobilizing for 'a three-day labour.'

The above quoted NKVD reports left the number of deceased during the march unsaid, but we learnt from the survivors that prisoners who had dropped behind the columns and had fainted because of distress had been executed by the guards on the spot. Thousands of prisoners kept in GUPVI camps fell victims of starvation, cold, and contagious diseases. Headcount deficiency was refilled with Roussine, Ukrainian, and other nationalities from the settlements of call. It often happened that star-gazers were pushed into the lines of marchers. Due to such brutality, lots of Slovaks, Romanians, Ukrainians, Polish, Roussines, Jews, and other nationalities, but also priests and communists got into the transports and transit camps. The names of about seven thousand victims out of 130 settlements populated by Hungarians can be read on the Wailing Wall in the Memorial Park of Szolyva (Свалява [Szvaljava]). Thirty percent of the deported (out of forty thousand) never returned (Dupka 1913). The aggressive deportations, inhumane treatment killed thousands of people. We know it from notebooks, memories, noted down strips of recollections of the survivors that the sadism of the organizers and executors of the deportations and internment went one better than that of the fascists (Élő történelem / Living History, 1913).

Analysing the full report, it appears that the number of imprisoned policemen and gendarmes (so emphasized by the Decree) was only 185 and the confiscated firearms were less than 100. The great number of soldiers and officers needs some explanation. Viz. it turned out from the archival materials that in case of the arrested the military rank that was primarily taken into consideration was the one they had in the Czechoslovakian army. These soldiers and officers had not been lurking. Living with their families they thought their military service was over for good and so they were not afraid of presenting themselves voluntarily.

The Hungarians and Germans of military age were all civilians, i.e. they had nothing to do with the army, the police or the gendarmerie. It can be also known from archival documents and from the oral accounts of the participants of those events that later on, besides them, the authorities also arrested and sent to the Gulag people who could be persecuted criminally neither in war times nor after it, but in spite of this the state security guards deemed them suspicious. The NKVD organs watched them vigilantly even in the camps.

It is another shocker how self-confidently and 'openly' the operation was carried out under the false allegation of 'the three-day labour'. In those days, 
the leadership of the People's Council of Transcarpathian Ukraine was doing preparations for a very significant political event of the country, and the situation that evolved was not immaterial for party leader Ivan Turyanitsa, who would later become Secretary of the Central Committee of the Communist Party of Transcarpathian Ukraine. On the $19^{\text {th }}$ of November, 1944 (it was the other day after the arrest of the most significant part of 'the crowd designed for isolation'), the first Congress of the Communist Party of Transcarpathian Ukraine was opened, where the long-range questions of the activity of the county's party organ and the reunion of Transcarpathian Ukraine with Soviet-Ukraine were discussed.

A week later, on the $26^{\text {th }}$ of November, the first congress of the People's Council of Transcarpathian Ukraine was held, which had to accept the Manifesto declaring the reunion of Transcarpathian Ukraine with Soviet-Ukraine. Under these circumstances, the operation aimed at the arrest of 'the isolated elements of the population' was most likely deemed a necessary part of the plan designed for ensuring state security and public order.

Regarding the approach to the Hungarian population, it is worth quoting a practically obligate confession of Lieutenant-General Pronin, the head of the political group of the $4^{\text {th }}$ Ukrainian Front: 'The political situation in these days (after the signing of the Manifesto declaring the reunion of Transcarpathia with Ukraine) has become much more complicated and worse. Until the Congress, local Hungarians received the entry of the Red Army into Transcarpathian Ukraine if not gladly but by no means with hostility. But now that the state security organs singled out nearly thirty thousand Hungarians of military age, the greater part of the Hungarian population and part of the pro-Hungarian Ukrainians express their discontent and starting maladjustment in a way. It is expressed primarily by agitating against the Manifesto' (TSU 2007: 390. doc. 619-665). As is known, all this had happened well before Transcarpathia became Soviet territory.

The eyewitness László Sándor in his memoirs recollects these days as follows: '... after the Congress, the following code-word appeared in Russian and Ukrainian in the daily papers and on different placards: Long live the reunion of Transcarpathian Ukraine with Soviet-Ukraine! The local Hungarian and Roussine population read the code-word with surprise because they did not ever know that Subcarpathia had once been part of Ukraine. Even the learned intelligentsia did not ever hear that this territory had once belonged to Ukraine. But certain Soviet historians picked up their pens quickly and started writing a series of articles proving that Subcarpathia was once part of Ukraine, but these articles could not resolve the local population's doubts either' (Sándor 2009: 87). 


\section{References}

\section{Collected Archive Documents}

Шляхом Жовтня. Визволення Радянською Армією Закарпатської Украӥни і возз 'єднання ï̈ з Радянською Украӥною. Збірник документів. Т.6. (VIII. 1944. - I. 1946. pp.) Ужгород, 1965. 4.

Тернистий шлях до Украӥни. Збірник архівних документів і матеріалів „Закарпаття в європейській політиці 1918-1919, 1938-1939, 1944-1946 рр. ХХ століття.”. Упорядник: ДОВГАНИЧ, О. Д. ВАТ, Видавництво Закарпаття, Ужгород, 2007.

Закарпатські втікачі в СРСР: через табори ГУЛАГу і БУЗУЛУК до рідних Карпат. 1939-1949. Архівні документи і матеріали. Ужгород, Всеукраїнське державне видавництво Карпати, 2011. 42.

Карпатська Украӥна: Документи і матеріали, том І. Упорядкування: ДОВГАНИЧ, О.Д., КОРСУН, О. М. Ужгород, ВАТ, Видавництво Закарпаття, 2009. 353-355.

\section{Literature}

DUPKA György (ed.). 1993a. Egyetlen bünük magyarságuk volt. Emlékkönyv a sztálinizmus kárpátaljai áldozatairól. (Their Only One Sin Was Their Hungarian Identity. Memory Book of the Victims of Stalinism in Transcarpathia). UngvárBudapest: Intermix Kiadó.

1993b. Élő történelem. A sztálini haláltáborok túlélőinek vallomásai 19441957. (Living History. The Testimonies of Stalin's Death Camps Survivors 1944-1957). Intermix Kiadó.

1993c. „Sötét napok jöttek...” Koncepciós perek magyar elítéltjei. ('Dark Days Were Coming...' Hungarian Convicts of Show Trials). Ungvár-Budapest: Intermix Kiadó.

DUPKA György. 2012. A mi golgotánk. A kollektív bünösség elvének alkalmazása a kárpátaljai magyarokkal és németekkel szemben. (A 4. Ukrán Front Katonai Tanácsa határozatainak végrehajtása az NKVD-jelentések tükrében, 19441946) (Our Calvary. Applying the Principle of Collective Guilt against the Hungarians and Germans in Transcarpathia (The Execution of the Decisions of the Military Council of the 4. Ukrainian Front in the Perspective of the NKVD-reports, 1944-1946). Ungvár-Budapest: Szolyvai EmlékparkbizottságIntermix Kiadó.

2013. „Hova tûnt a sok virág...” Idôutazás az Urálba Magyar és német rabok (1941-1955) nyomában. ('Where have all those flowers gone...' Time Travel into the Urals. On the Traces of Hungarian and German Prisoners (1941-1945). Ungvár-Budapest: Intermix Kiadó. 
2014. A szovjet hatóság megtorló tevékenysége Kárpátalján (1944-1991). (The Repressive Activity of the Soviet Authorities in Transcarpathia (1944-1991). Ungvár-Budapest: Intermix Kiadó.

DUPKA György-KORSZUN, Olekszij. 1997. A „malenykij robot” dokumentumokban. (Malenkaya Rabota in Documents). Ungvár-Budapest: Intermix Kiadó.

КУЦЕНКО, К. О. 1970. Визволення Карпатська Украйни Радянською Армією (вересень-жовтень 1944. р.) Украӥнський історичний журнал, № 6.

SÁNDOR László. 2009. Három ország polgára voltam. Egy évszázadnyi élet emlékei. 1903-1993. (I Was the Citizen of Three Countries. Memories of a Century-Long Life. 1903-1993). Pozsony: Madách-Posonium.

\section{Studies}

DOVHANICS, O. D. 1997. A Vörös hadsereg csatái Kárpátalja felszabadításáért (The Battles of the Red Army for the Liberation of Transcarpathia). In: Ukrajna Emlékkönyve, Kárpátontúli terület 1. (Memory Book of Ukraine. Transcarpathian Area 1.). Ungvár: Kárpáti Kiadó.

KERECSANYIN, V. M. 1997. Utószó (Endnote). In: Ukrajna Emlékkönyve, Kárpátontúli terület 1. (Memory Book of Ukraine. Transcarpathian Area 1.). Ungvár: Kárpáti Kiadó. 